\title{
Tunnel and Microtunnel For Future Smart and Sustainable Infrastructure Solution
}

\author{
Siti Norafida Jusoh ${ }^{1}$, Abdullah Rini Asnida ${ }^{1}$ and Marto Aminaton ${ }^{1}$, Fauziah Kassim ${ }^{1}$ \\ ${ }^{1,2}$ Department of Geotechnics and Transportation, Universiti Teknologi Malaysia, Johor Bahru 81300 Johor, \\ Malaysia
}

\begin{abstract}
Underground facilities and tunnels is not a rare discussion anymore. More and more underground explorations were carried out as to fulfil the need of mankind. In this paper, discussion on how to utilise tunnel and underground space knowledge in order to sustain green development thus to provide smart solution for infrastructure facilities (electrical cable, manhole etc) is discussed. Types of tunnel and its excavation methods especially the recent micro-tunnelling method also presented. Affect to the green and sustainable development and case study are also presented.
\end{abstract}

Keywords—tunnel, micro tunnel, green sustainable development, smart solution

\section{INTRODUCTION}

$\mathrm{D}$ we add green space to our ever-growing cities?

Underground exploration has the answers. Tunnel has been used to solve the construction with limited ground surface capacity. When working underground, one's facing different geological condition of what's underground and thus give different degree of difficulties. In term of safety, it is riskier than the surface structures. Limited data of geological condition cause uncertainty during construction of tunnel. However, it is a smart solution to ensure green resilient mankind development. Hence, exploration of underground space currently becomes a well-known construction activity especially for a construction of a tunnel. With advantages of knowledge expansion nowadays, tunnel and underground work can benefits humankind in their own way.

As we know in underground, there is a lot of utilities includes telco lines water pipe, electrical cables, sewerage system and so on that need to be avoided during the construction building and infrastructure, in this paper, overview of trenchless technology to overcome this problem is carried out. In mean time, via trenchless technology, the green resilient environment can also be preserve. A case study involving protected species of one lake also shared in this paper to have new insight of the tunnelling benefits. Finally, at the last part of this paper, future emerging of solar technology to bring natural sunlight into tunnel/underground space to allow green environment also presented here in.

\section{TRENCHLESS TECHNOLOGY: THE MICRO TUNNELLING AND PIPE JACKING}

In cities and urban areas water and sewage infrastructure and other utility services located underground in pipes or ducts are laid, repaired or replaced by the conventional trenching methods. The open cut trenching methods create road closures, traffic delays, noises and general disruption. This makes repair and rehabilitation of subsurface utilities difficult, particularly in areas congested with traffic and buildings. Lack of repair and rehabilitation of the pipeline for the water disruption and sewage systems lead to leakages and waste water seepages, resulting in the contamination of water distribution system and groundwater. These problems often give rise to related health and environmental impacts.

The demands for alternative technology lead to the emergence of trenchless Technology, which includes a family of methods utilized for installing and rehabilitating underground utility systems with minimum ground surface disruption and destruction as compared to open cut excavation methods. Trenchless technologies and methods provide an effective, environmentally sound alternative for the installation, maintenance and repair of underground utility services.

The appropriate application of trenchless Technology for resolving both Engineering and Environmental problems can be viewed as an environmentally sound technologies. In addressing urban sanitation problems, Trenchless Technologies have the potential to yield significant environmental and other benefits such as employment opportunities reduced inconvenience to commuters, reduced fuel consumption and improved traffic flow.

New installation, or replacement or rehabilitation of any related underground piping installation (such as electrical, fiber optic, gas, water, sewerage etc) can be minimal disruption with trenchless technology. Hence, engineers/builders can maintain the surface traffic, business and other activities as trenchless provide effective and fast working tools compared to open trenching that lead to major disturbance of surface activities.

Mini-horizontal directional drilling (by pipe jacking) and micro tunnelling are the best known method that used in trenchless construction. 
Micro tunnelling method is very cost-effective compared to open-cut construction. This method should be referred to the process, without arbitrary size constraints. It allowed for pipelines to be installed in congested urban or environmentally sensitive areas, at depth greater than $15 \mathrm{ft}$, in unstable ground or below the water table.

This method is a good alternative new method since it can used in vast ground properties from soft clay to rock or boulder ground, up to $100 \mathrm{ft}$ below the water table without need for de-watering[1]. The capacity on production rate was excellent, usually around 30 to 60 $\mathrm{ft} /$ day and once reported achieved $200 \mathrm{ft} /$ day in good ground conditions [1]

Micro tunnelling method has been used to install concrete, steel, centrifugally spun-cast polyester resin, fiberglass-reinforced (Hobas or GRP), and vitrified clay pipes[1]. A small quantity of PVC pipe has been installed using the system. Although sewer construction is the primary application, potential applications include environmental remediation work, such as horizontal cutoffs below a contaminated site or waste plume. Two operating systems are available-slurry and augur-which are distinguished by the means of spoil removal [1]. The slurry system has enhanced capabilities for applications below the water table, though at some cost and complexity penalty over auger systems [1]. Both systems have been reported successfully used in Europe, Japan and the United States.

\section{A. Pipe roofing installation by micro tunnelling method} in Maluri underground KVMRT Station Entrance A

A pipe roofing structure for respective underground construction was highlighted to show capability of micro tunnelling and pipe jacking in top-down tunnel construction. By adopting this method, smart solution to sustain green development and in the same time saving the cost, cut the construction time and ensuring smooth traffic movement was established in this project. A pipe roof of $780 \mathrm{~mm}$ diameter steel pipes of $10 \mathrm{~mm}$ thick was installed under the busy Jalan Cheras for Entrance A of Maluri Station of southernmost KVMART underground station[2]. The Enterance A poses the greatest challenge due to the existence of utilities buried under this section. The utilities includes Telco lines, a $600 \mathrm{~mm}$ SYABAS water pipe, and most importantly, $275 \mathrm{kV}$ Tenaga Nasional Berhad (TNB) high voltage electrical cables. The electrical cables serve as the main supply source to Bukit Bintang region [2] (Figure 1). Figure 2 shows the plan for pipe roofing installation above the tunnel adit structure.

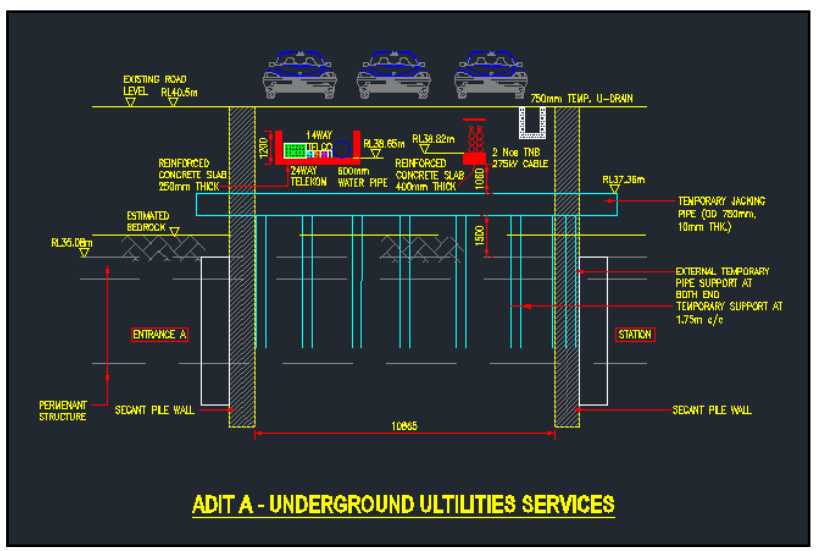

Figure 1 Site [2]

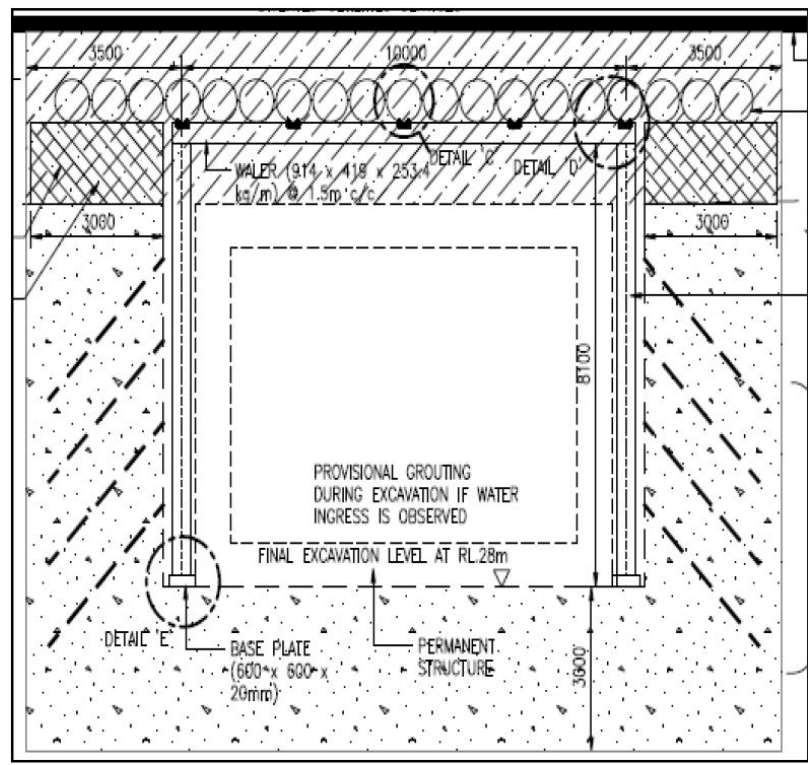

Figure 2 Pipe roofing installation plan above the tunnel adit structure [2]

This pipe roof structure consists of 17 steel pipes of $780 \mathrm{~mm}$ outer diameter with $10 \mathrm{~mm}$ thickness. The length of pipe was $17.8 \mathrm{~m}$ long, with $13 \mathrm{~m}$ of the pie is underground and the remainder protrudes equally at both ends [2]. In order to install the $780 \mathrm{~mm}$ diameter steel pipes, a Herrenknecht AVN500XC pipe jacking matching was used with an attached rock cutting head of $826 \mathrm{~mm}$ in diameter for overcut purposes. Stitch coring also applied to allow direct assess of the machine into the ground (Figure 3). For this purpose, a separation plant from slurry treatment was suitable for the site conditions and helps to improved productivity in the silty ground condition. Bentonite was pumped to help expedite the pipe advancement. Annulus grouting was applied after the completing of each drives. Figure 4 shows the sequences involved in this project. Figure 5 shows the jacking frame setup process of individual drive. 


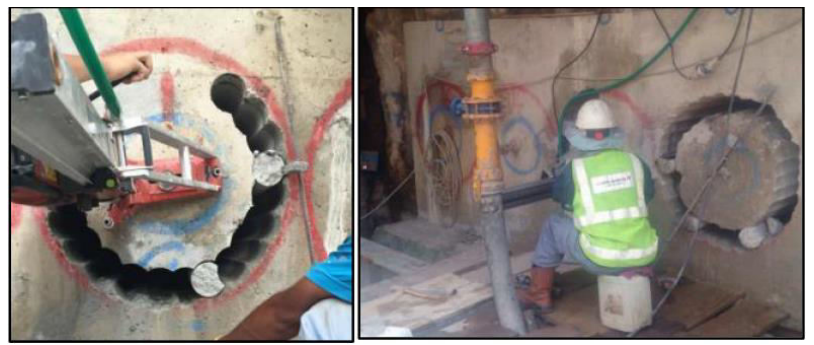

Figure 3 Stitch coring of secant bored pile to allow direct access of machine to ground [2]

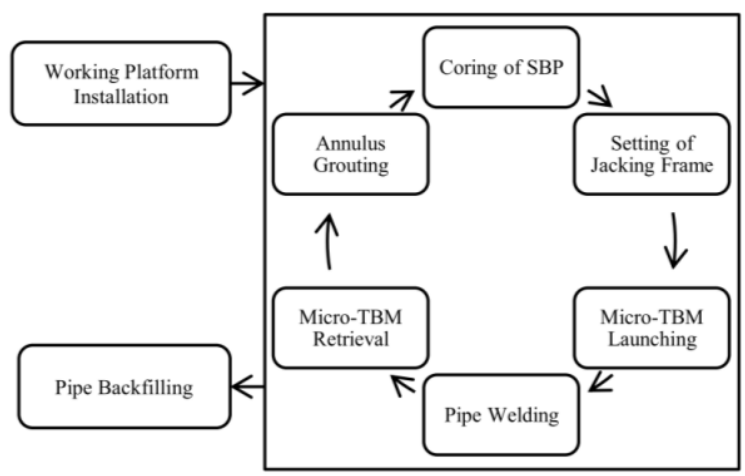

Figure 4 Pipe roof installation sequence [2]

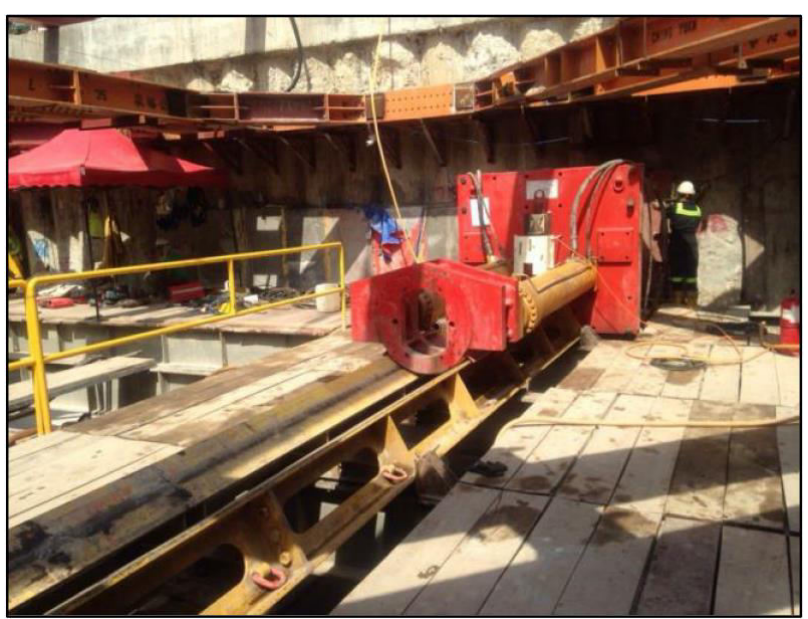

Figure 5 The jacking frame setup process of individual drive [2]

B. River Diversion with Triplet Tunnel using Mirco tunnelling

In a PLUS Highway underpass project, a drainage box culvert are found needed to be replaced by three series of $3 \mathrm{~m}$ diameter pipes installed under the highway for river diversion (Figure 6). As the cover of the drainage box system was only have $4 \mathrm{~m}$ overburden, the settlement induced from this construction need to be as minimal it could to preserve the highway services. Hall from Gamuda in 2010 reported in this project, by means of micro tunnelling method, this project not only succeed conducted but also successfully manage to have only minimal ground settlement [3]. By using bentonite slurry micro tunneling/pipe jacking machine, this slurry machine was successfully being used to support the face and avoid settlement of the highway. RASA $3.5 \mathrm{~m}$ diameter of cutter head was chosen to work through the ground that comprises of compacted fill and alluvium.
Figure 7 presents the drainage micro drive breakthrough in this project.

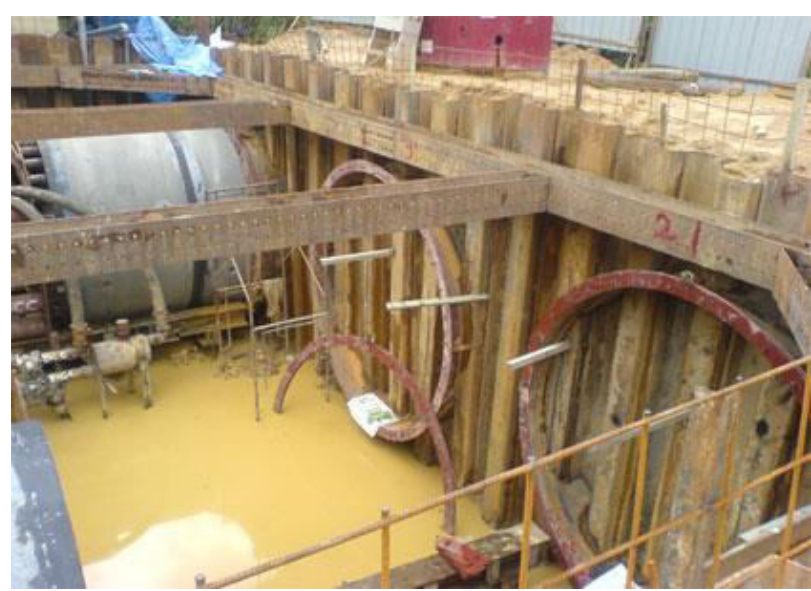

Figure 6 Three $3 \mathrm{~m}$ drainage microtunnels to divert the river flow (Hall, 2010)

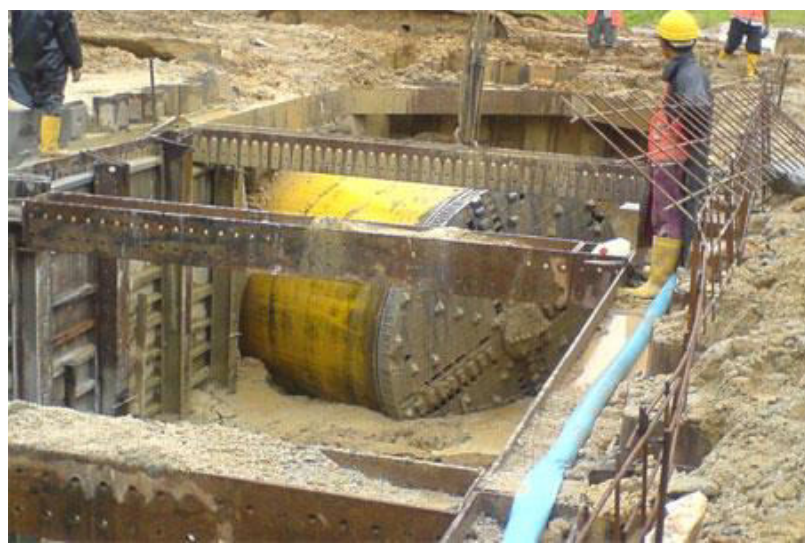

Figure 7 Drainage micro drive breakthrough (Hall, 2010)

\section{Micro tunnelling in Malaysia for river health}

Kuching City on Sarawak has a population of 500,000 yet currently lacks a centralised sewer system[4]. Due to this factor, surrounding rivers such as Sungai Bintang or and Sungai Maong are heavily polluted by the discharge of partially treated and untreated sewerage [4]. Therefore, sewer systems with gravity flow application then were installed in depths ranging from 6 to $27 \mathrm{~m}$ [4]. This sewer system is a part of Central Sewage Treatment Plant and the end of project will install $64.1 \mathrm{~km}$ of sewers. It includes a $7.7 \mathrm{~km}$ trunk sewer, $5.4 \mathrm{~km}$ of secondary sewer, and $51.4 \mathrm{~km}$ of tertiary sewer, which will be $450-1,500 \mathrm{~mm}$ in diameter. The aims of this project is to create a high quality sewer system composed of sewers and wastewater plants, ensuring that only Standard A wastewater is discharged into the surrounding environment. To ease the project installation, micro tunnelling had been chosen to play a major role in this project[4]. 


\section{Indian Trenchless Market}

India is highly dense in terms of population. With rapidly growth of population, it is estimated that almost half of Indias 626 districts will require upgrades in utility infrastructures. Around 63 cities identified in JNNURM (Jawaharlal Nehru National Urban Renewal Mission) are considered to be a priority for development[5].

As aims to reduce the environmental impact of developing and operating sewage treatment networks, underground interceptors constructed using trenchless methods chosen as a positive solution in densely populated cities, especially those located along river banks[5]. According to the JNNURM plan, the total value of trenchless projects being developed in the 63 priority cities is around USD 23 billion[5].

Trenchless work initiated in the cities of Delhi, Mumbai, Kolkata, Bangalore, and Hyderabad. Primarily, these projects are for installing water and sewer pipes and are being constructed using pipe jacking or micro tunnelling methods. HDD has been used for Optical Fiber Cable (OFC) laying for telecom and internet service provider companies.

Pipe rehabilitation projects using trenchless methods as well as pipe ramming and pipe jacking projects are also being carried out in the cities of Delhi, Kolkata, Bangalore, Chennai, Hyderabad, Cochin, Ahmadabad, and other Tier-II cities. Although HDD is a fairly popular trenchless method in India, other methods are not as widespread based upon the number of machines currently in use. For auger boring, there are currently no more than 60 auger machines in use across India. For micro tunneling, there are less than 30 micro tunnel boring machines (MTBMs) in use[5].

\section{GREEN TODAY GREENER FUTURE}

To preserve our green resilient urban infrastructure environment, tunnel and underground excavation can be a choice to achieve this aim. A new holistic approach by using underground construction that preserve the beautiful scenery and in the same time can protect the protected species give new point of view the way we utilise our ground. A case study involving protected species of one lake also shared in this paper to have new insight of the tunnelling benefits.

A. Ennerdale lake - fish pass; West Cumbria water supplies project

Ennerdale, a lake and River Ehen, play host to protected species. It is owned by United Utilities, is a deep glacial lake, 2.5 miles $(3.9 \mathrm{~km})$ long with $3 / 4$ mile ( $700 \mathrm{~m}$ to $1.5 \mathrm{~km}$ ) wide and 148 feet deep (45 m deep). Ennerdale Water is fed by the River Liza and other streams, and in turn feeds the River Ehen, which runs to the Irish Sea[6]. The water in it is exceptionally clear and contains a variety of fish. Besides a playhost of protected species, it also play an important role of supplying water to about 80000 people in Whitehaven and the surrounding areas[6].

Legal restrictions and conditions (consents) govern how much water can be taken from the lake and how much to be put back to keep the River Ehen flowing. These are set by the Environment Agency to protect the environment. Ennerdale Water has been used for water supplies for more than 150 years[6]. Therefore, to ensure the amount of water taken form these respective naturally occurring water sources is in controlled, without damage risk to long-term wildlife nature/minimal long term environment impact, government of England has proposed regional water network via a major new pipeline from Thirmere to West Cumbria that include new water treatment works, pumping station and underground service reservoirs. Details of the work include:

i. New additional pumps and treatment units at Ennerdale Water Treatment Works

ii. A new $13 \mathrm{~km}$ pipeline from South Egremont to Ennerdale Water Treatment Works

iii. New boreholes at south Egremont linking to the new pipeline

In the meantime, to protect the valuable species, fish pass also introduced to allow the fish to get up to the River Ehen (Figure 8). United States also re-introducing natural rocks and gravels to make the river bed and blocking the pie which was put to divert the river (i.e., river to boost the water supplies) [6]. A permanent underground pump station solution also installed unsightly to ensure he beautiful landscape of the lake can be preserved (Figure 9) [6]. All of this effort was carried out to ensure to keep the River Ehen flowing, even when the West Cumbria project is completed.

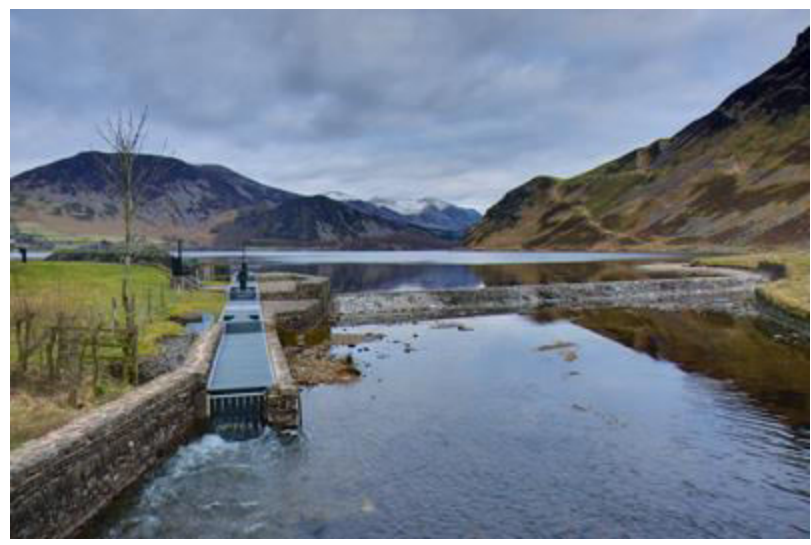

Figure 8 Ennerdale lake fish pass

(http://cumbria.unitedutilities.com)

\section{FUTURE SMART SOLUTION IN EMERGING NEW MANKIND NEEDS: NEW YORK CITY LOWLINE}

Although with advance tunnel and underground technology, the human reactions during time spent underground have not been scientifically investigated. There were three important aspects to be considered 
when in tunnel or underground, i) the entrance, ii) what inside and iii) what will happen to me when I am there. For aspect ii and iii, an example smart solution has been proposed in New York City Lowline projects. By using solar technology, a historic trolley terminal - untouched since 1948 was transform into a beautiful public gathering area that's complete with live plants and trees[7]. This Lowline park plans to collect sunlight on the surrounding rooftops and use efficient mirrors to reflect the light down to street-level (Figure 10). The collection will then be directed underground via a series of tubes. Lowline anticipates a lot of sunlight accumulation, therefore, there will be many different types of plant species living underground in the middle of a crowded Manhattan.

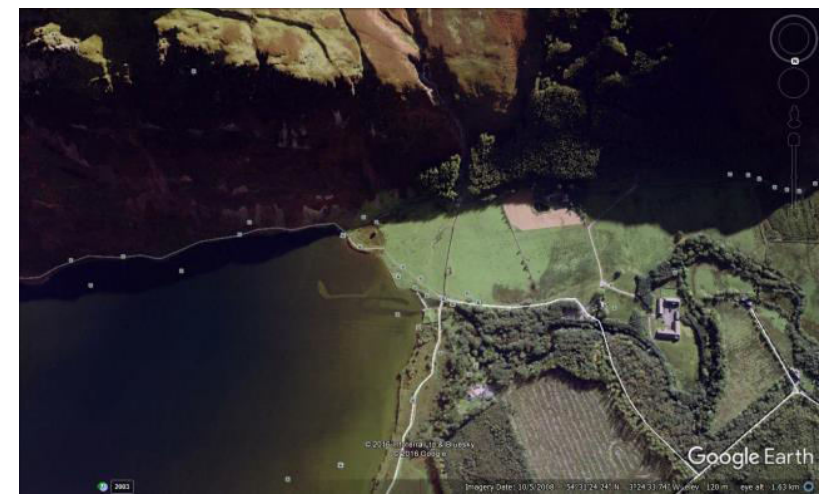

Figure 9 Aerial photo of Ennerdale lake that still preserves beautiful scenery with underground pump station solution (From google earth)

In 2012, exhibition of Imagining the Lowline had installed a solar collection system in a warehouse and gave people an idea of how the space would look and feel(Figure 11)[7]. The forgotten Trolley Tunnel changed into world's first underground park. By using a system of mirrors - similar to concentrated solar power mirrors - that pivot and rotate to follow the sun's journey across the sky. Once complete, the Lowline will be sourced by more than 100 of these collectors-large parabolic dishes that concentrate sunlight into beams 30 times the strength of the light experienced by pedestrians on the street[7]. By help of solar technology, this finding of enhancing the underground system might help to expand the utility of underground in near future.

\section{CONCLUSION}

The innovative and smart solution found and lessons learned on this project are applicable for future urban infrastructure planning. As geotechnical aspects of each project presents unique challenges, best results are achieved when a team takes a holistic approach to solve issues faced by the client and in the same time understands the various impact on local communities and applied the most appropriate and effective solution.

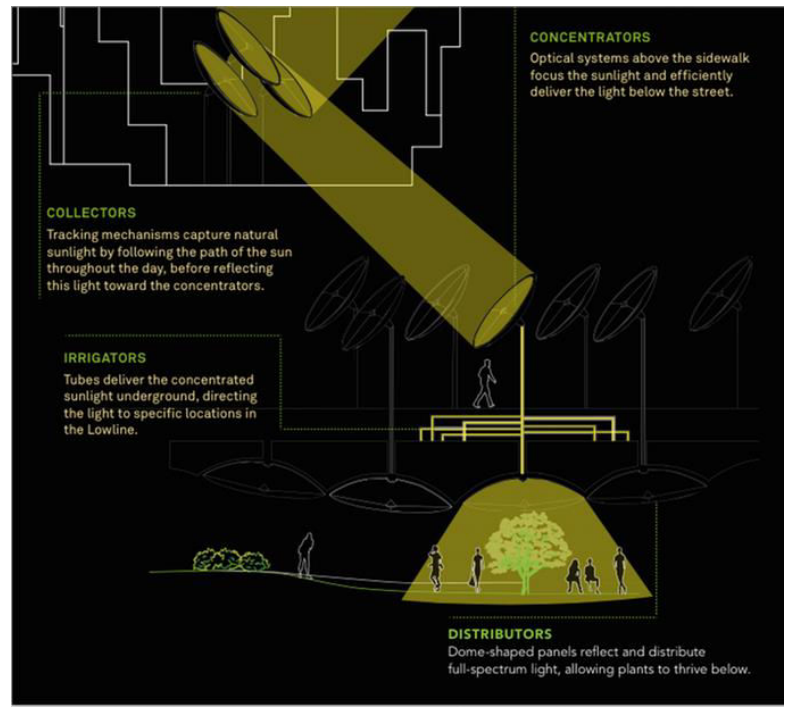

Figure 10 A natural sunlight channeled into the cavern by an intricate arrangement of solar collectors, mirrors, and a transparent tube system (http://mymodernmet.com/nyclowline-underground-park/)

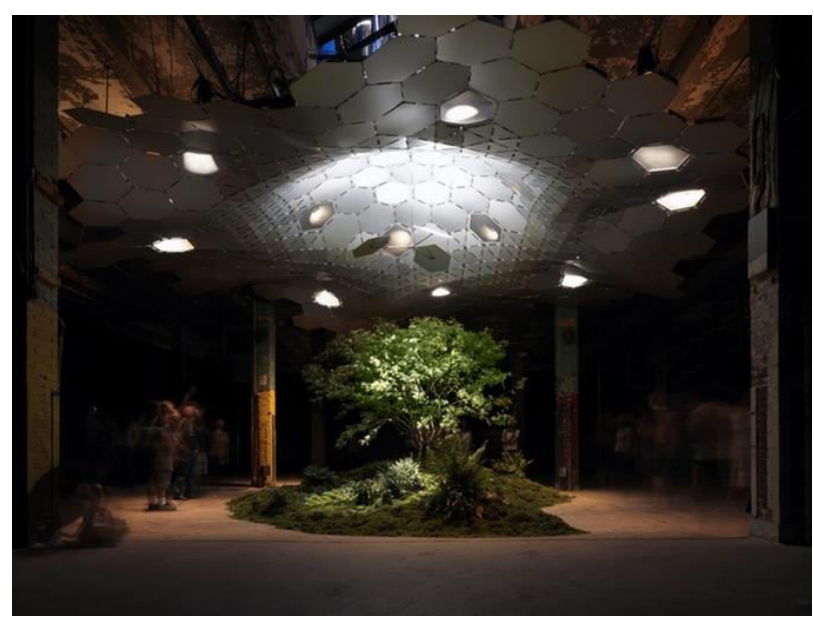

Figure 11 Laboratory testing in warehouse on natural sun light system into underground world

\section{ACKNOLEDGEMENT}

Mass Rapid Transit Corporation Sdn Bhd (MRTCorp), Maluri Station Team for sharing the information on the project.

\section{REFERENCES}

[1] Ian Lisk,"Trenchless Technology: A Review of the Methods," North American Society for Trenchless Technology (NASTT) whose annual conference and exposition, NO-DIG '97, Seattle, Washington, from April $18 \quad-21 . \quad$ (Available at : https://www.wateronline.com/doc/trenchless-technologya-review-of-the-methods-0001)

[2] H.W. Ng, K.C. Lin, I. Leong, D. Hafez,"Pipe Roofing Installation by Micro Tunnelling Method," Southeast Asian Conference and Exhibition in Tunnelling and Underground Space 2017 (SEACETUS2017) Subang Jaya, Malaysia, 18-19 April 2017

[3] Don Hall, "Record rail tunnel break through in Malaysia," TunnelTalk, Nov 2010. (available online at: https://www.tunneltalk.com/Malaysia-Nov10-Berapittunnel-breakthrough.php) 
[4] Annie Ferguson, "Microtunnelling in Malaysia for river health," Trenchless International Publication, United Kingdom, 2010 (available online at : https://www.trenchlessinternational.com/2010/05/02/micr otunnelling-in-malaysia-for-river-health/)

[5] S.K. Daddala, M. Mohidin, "Study of Trenchless Technology," International Journal of Scientific Research in Science, Engineering and Technology (ijsrset.com), Volume 2, Issue 6, 2016. Print ISSN: 2395-1990| Online ISSN : 2394-4099, (available online: https://www.academia.edu/29970250/Study_of_Trenchles s_Technology
[6] United Utilities, "West Cumbria Water Supplies Project," United Utilities England, 2017 (available online at : http://cumbria.unitedutilities.com/west-cumbriaplanning.aspx)

[7] Sara Barnes, "NYC's Lowline to Turn Forgotten Trolley Tunnel into World's First Underground Park," July, 2015 (available at : http://mymodernmet.com/nyc-lowlineunderground-park/) 